\title{
The control of hypertension in men and women: a comparative analysis
}

\section{O controle da hipertensão arterial em mulheres e homens: uma análise comparativa El control de la hipertensión arterial en mujeres y hombres: un análisis comparativo}

\section{Stael Silvana Bagno Eleutério da Silva ${ }^{1}$, Sofia de Fátima da Silva Barbosa de Oliveira², Angela Maria Geraldo Pierin ${ }^{3}$}

\section{How to cite this article:}

Silva SSBE, Oliveira SFSB, Pierin AMG. The control of hypertension in men and women: a comparative analysis. Rev Esc Enferm USP. 2016;50(1):50-8. DOI: http://dx.doi.org/10.1590/S0080-623420160000100007

${ }^{1}$ Universidade de São Paulo, Escola de Enfermagem, Programa de Pós-Graduação em Enfermagem na Saúde do Adulto, São Paulo, SP, Brazil.

${ }^{2}$ Universidade de São Paulo, Faculdade de Saúde Pública, São Paulo, SP, Brazil.

${ }^{3}$ Universidade de São Paulo, Escola de Enfermagem, Departamento de Enfermagem Médico-Cirúrgica, São Paulo, SP, Brazil.

\begin{abstract}
Objective: To compare men and women who have hypertension with reference to the following: high blood pressure, biosocial variables, habits and life styles, mental disorders, and social support networks. Method: 290 hypertensive patients (women, 62.1\%) were evaluated. The assessments involved the following: measuring blood pressure with an automatic measuring device, evaluating social status through the Social Support Scale, and the use of a Self-Report Questionnaire (SRQ-20) to identify common mental disorders. A value of $\mathrm{p}<0.05$ was considered statistically significant. Results: Women were found to be different to men $(p<0.05)$ in the following areas having: better control of their blood pressure $(64.4 \%$ vs $52.7 \%)$, less salary incomes, less diabetes, higher total cholesterol, higher body mass index and wider abdominal circumferences. They also had lower systolic blood pressure, lower levels of alcohol consumption and a greater prevalence for mental disorders. The social support assessment revealed that hypertensive women received less help with preparing meals but had more company from people which allowed them to engage in enjoyable activities. Conclusion: Women had more control over their blood pressure than men, despite the presence of negative biopsychosocial factors that may have influenced their adherence to the treatments.
\end{abstract}

\section{DESCRIPTORS}

Arterial Pressure; Women; Hypertension. 


\section{INTRODUCTION}

High blood pressure is one of the biggest current public health problems. It is one of the main risk factors for cardiovascular diseases, which in the last decade represented the leading cause of deaths in the world. Cardiovascular diseases were responsible for approximately $30 \%$ of all deaths and for up to $50 \%$ of deaths that were linked to a group of nontransmissible $^{(1)}$ chronic illnesses. A study which involved systematic reviews of specific journals from 35 countries showed a global trend in cases of hypertension showing that it was prevalent in $37.8 \%$ of men and $32.1 \%$ of women ${ }^{(2)}$.

Information for the year 2013 from the Center for the Monitoring of Risk Factors and the Protection against Chronic Diseases via Telephone Research (hereafter VIGITEL) revealed the frequency of early diagnosis being $24.1 \%$ for the adult population from 27 Brazilian capitals that were studied. Of those that were studied, the number was a little higher for women (23.6\%) in comparison with men (21.5\%). ${ }^{(3)}$ The VI Brazilian Guidelines for Hypertension stated that the global trend for hypertension amongst men and women are similar although the numbers are higher for men up to the age of 50. The numbers increase for women after this age ${ }^{(4)}$. This has been attributed to hormonal climacteric changes that occur due to the menopause which can expose women to cardiovascular problems. Continuing on this vein, a study involving the research of journals showed a direct linked between high blood pressure in women and a high risk of encephalic vascular accident ${ }^{(5)}$.

In spite of all of the knowledge and evidence on the importance of early diagnosis and treatment of arterial hypertension, the levels of control of this disease is still proving to be a major challenge for health care professionals. With this in mind, a study of those with high blood pressure who received treatment from their primary health care service showed that $54.4 \%$ of them did not show any form of control over their condition. It also showed that women had more control over their condition than men $(\mathrm{p}<0.05,30.9 \%$ vs $52.6 \%$, respectively) ${ }^{(6)}$. This lack of control, in many cases, can be attributed to the suffers not adhering to the required treatment which, amongst other factors, interferes with the process. What also needs to be taken into consideration in relation to the chronic nature of the disease and the medical treatment, is that fact that the treatment is necessary for the rest of someone's life. Also consideration was given to the undesirable effects of the drugs used and the dosage of the drugs given. In cases where medication is given in the treatment, the requirement to change one's habits and life styles can be difficult for suffers. There are also other factors which govern whether someone will adhere to the treatment such as: the characteristics of the hypertension, the age and gender of the person, whether there are other chronic diseases associated with the hypertension such as Diabetes Mellitus, obesity and alterations of the lipid profile.

In our current society women's roles are still often determined based on their gender. This is particularly the case in the family context as well as in the world of work which often means women being exposed to unfavorable work- ing conditions. Due to this fact women experience physical changes in their appearance and develop psychological signs and symptoms such as: depression, anxiety, insomnia, fatigue, irritability and somatic complaints defined as common mental disorders ${ }^{(7)}$. Also at the outset of hypertension, psycho-economic factor are also relevant. It was noted that a social support network made out of family members, friends and neighbors can be a great ally in facing chronic diseases such as arterial hypertension.

With the above in mind for arterial hypertension where the aim is to control the tension levels, what is being questioned is whether women with this condition present characteristics that are different to men with the same condition. Based on these considerations, the aim of this study was to compare men and women with the same condition in relation to: bio/psycho/social-variables, habits, life styles (the consumption of alcohol, physical activity and smoking), the presence of common mental disorders, social support, and the control of arterial hypertension.

\section{METHOD}

An exploratory, transversal study was carried out that took a quantitative approach that was a part of a Public Policy Project which was sponsored by the Amparo Foundation. This was research done through the State of Sao Paulo (hereafter FAPESP) and it was approved by the Ethics Committee on Research (N213/03). The sample was calculated through consideration being given to the prevalence of hypertension in 30\% of those studied, which resulted in us evaluating 290 people with hypertension. The study was carried out on those with hypertension that paid visits to two basic health centers in the western region of the municipality of Sao Paulo in Brazil. The criteria used in order to be included in the study were: people over the age of 18 years old, those with hypertension, those that had been undergoing treatment for approximately six months and those that would sign the Consent Form of their own free will once the terms had been explained. The following people were excluded: pregnant women with hypertension where hypertension occurred as a result of their pregnancy, those with a history of drug abuse and those with mental disorders. It was thought that those with mental disorders would not have been in a position to freely sign the Consent Form without there being doubts as to whether their condition affected their ability to understand what they would sign and what they would subsequently undergo.

\section{Collected Data}

Data was obtained through interviews that followed a prescribed format. This tool was drafted based on the literature and clinical experience of the researchers. The biosocial variables included: age, gender, ethnicity (race was self-declared), marital status (with or without a partner), level of education (illiterate, primary school education, high school or university education), household income ( $\leq 3$ or $>3$ in minimum salaries), weight, height to calculate the body mass index, the circumference of the abdomen and blood 
pressure readings. We also evaluated comorbidities such as: diabetes, dyslipidemia, acute myocardial infarction and encephalic vascular accident. We evaluated the following: physical activity (approximately three times per week, for 30 minutes), whether the person was a smoker (yes/no) and alcohol consumption (AUDIT test). In relation to physical activity, those that were considered active were individuals that carried out physical activity approximately three times per week in accordance with the VI Brazilian Guidelines on Hypertension ${ }^{(4)}$.

Blood pressure was measured three consecutive times with a reputable automatic device that adequately fits around the circumference of the arm when a person is seated. This is in accordance with the VI Brazilian Guidelines on Arterial Hypertension ${ }^{(4)}$. The average for the last two readings were used in the analysis, bearing in mind that the first reading was significantly higher than the others. Such a situation could be due to the reaction to the alarm caused by the device for measuring pressure which causes a high reading and which is known as the phenomenon of the white apron. The control of blood pressure was considered through values for systolic blood pressure of less than $140 \mathrm{~mm} \mathrm{Hg}$ and diastolic blood pressure of less than $90 \mathrm{~mm}$ $\mathrm{Hg}$. Alcohol consumption was evaluated through the use of the Alcohol Use Disorders Identification Test - AUDIT ${ }^{(9)}$, asking the following question: "How often do you drink alcohol?". In accordance with the norms for the use of this tool, which was valid for our study, those that said they drank or had stopped drinking less than a year from when the study started, they were considered positive in having consumed alcohol for the purpose of the study. Those that said they had never drunk alcohol were considered negative in relation to alcohol consumption. The rest of the AUDIT Test questions analyzed quantitative and qualitative data covering data on alcohol consumption that was not included in the study Self Report Questionnaire (SRQ 20)(10) This data was used to analyze psycho-emotional aspects. This tool evaluated the presence or not of common mental disorders and was used in basic health care centers. It was composed of 20 dycotomic questions (Yes/No) with four questions on physical symptoms and 16 in relation to psycho-emtional disorders. The Social Support Scale was used which was validated in $\mathrm{Brazil}^{(11)}$. It was composed of 19 questions covering five functional dimensions of social support: material (questions 1 to 4), affection (questions 5 to 7), emotional aspects (questions 8 to 11 ), information (questions 12 to 15 ) and positive social interaction (questions 16 to 18). The possible responses for each question and their respective scores were: never (1), rarely (2), sometimes (3), almost always (4) and always (5). The presence of common mental disorders was considered positive for men that scored greater than or equal to six and for women greater than or equal to eight.

The data was collected by two post graduate nurses and three student nurses who specialized in scientific research. The training included having meetings where discussions were had with the coordinator on: the study itself, the tools used to collect the data, procedures for measuring blood pressure and anthropometric measurements of weight, height and abdomen circumference. Statistical analysis was done using the Statistical Package for Social Sciences (SPSS) version 7.5 software program. In relation to the descriptive classification variables, tables containing absolute frequencies (n) and relative frequency (\%) were used. Tables were also used for continuous data, averages and divergences from the norm. The Chi-square test was used to analyze the differences between women and men in relation to variable categories such as: ethnicity, level of education, marital status, income, life style habits, comorbidities, the social support scale and common mental disorders. The continuous variables included blood pressure values, body mass index and age, using the $\mathrm{T}$ test for students. The level of significance was determined as $\mathrm{p}<0.05$.

\section{RESULTS}

From the sample that was studied, the majority (62.1\%) were women. The women presented significantly different results $(p<0.05)$ from the men, respectively, in relation to: monthly incomes being less than three minimum monthly Brazilian salaries (72.6\% vs $55.3 \%$ ), high cholesterol levels ( $47.3 \%$ vs $32.7 \%)$, less prevalence of diabetes $(23.5 \%$ vs $36.7 \%)$, less consumption of alcohol (14.2\% vs $37.5 \%)$ and higher body mass indexes [29.96 (5.42) vs 28.71 (5.39), $\left.\mathrm{Kg} / \mathrm{m}^{2}\right]$. In respect of the abdomen circumference readings, in spite of the women having presented significantly lower values than the men [98.92 (16.45) vs 102.28 (14.3), cm], it is worth emphasizing that these values were higher than the norm. The women also had lower systolic pressure values [136.6(21.5) $\mathrm{mm} \mathrm{Hg}$ vs 142.5(23.5) $\mathrm{mm} \mathrm{Hg}, \mathrm{p}<0.05]$, however blood pressure control was higher for the women than the men ( $\mathrm{p}<0.05,64.4 \%$ vs $52.7 \%)$. With reference to the rest of the variables: age, ethnicity, marital status, smoking habits, physical activity and diastolic pressure, the two groups were very similar (Table 1).

It was observed, in accordance with the data from $\mathrm{Ta}^{-}$ ble 2 , that there was a higher percentage of women that had common mental disorders than men $(62.8 \%$ vs $30.8 \%$,

Table 1 - Distribution of those with hypertension based on gender in relation to biosocial variables, life style habits, the presence of associated illnesses and the control over blood pressure. São Paulo, SP, Brazil, 2010.

\begin{tabular}{|c|c|c|c|c|c|c|c|}
\hline \multirow[t]{3}{*}{ Variables } & \multicolumn{7}{|c|}{ Gender } \\
\hline & \multicolumn{2}{|c|}{ Male $N=110$} & \multicolumn{2}{|c|}{ Female $\mathrm{N}=\mathbf{1 8 0}$} & \multicolumn{2}{|c|}{ TOTAL $\mathbf{N}=\mathbf{2 9 0}$} & Value $p$ \\
\hline & $N$ & $\%$ & $N$ & $\%$ & $N$ & $\%$ & \multirow{4}{*}{0.908} \\
\hline Ethnicity & & & & & & & \\
\hline White & 59 & 56.2 & 99 & 56.9 & 158 & 56.6 & \\
\hline Non-White & 46 & 43.8 & 75 & 43.1 & 121 & 43.4 & \\
\hline
\end{tabular}




\begin{tabular}{|c|c|c|c|c|c|c|c|}
\hline \multirow[t]{3}{*}{ Variables } & \multicolumn{7}{|c|}{ Gender } \\
\hline & \multicolumn{2}{|c|}{ Male $\mathrm{N}=\mathbf{1 1 0}$} & \multicolumn{2}{|c|}{ Female $N=180$} & \multicolumn{2}{|c|}{ TOTAL N=290 } & \multirow[t]{2}{*}{ Value $p$} \\
\hline & $\mathbf{N}$ & $\%$ & $\mathbf{N}$ & $\%$ & $\mathbf{N}$ & $\%$ & \\
\hline Marital Status & & & & & & & 0.212 \\
\hline Without a partner (m/f) & 37 & 34.3 & 75 & 41.7 & 112 & 38.9 & \\
\hline With a partner $(\mathrm{m} / \mathrm{f})$ & 71 & 65.7 & 105 & 58.3 & 176 & 61.1 & \\
\hline Level of Education & & & & & & & 0.772 \\
\hline Illiterate/ Read and Write & 25 & 24.0 & 45 & 26.5 & 70 & 25.5 & \\
\hline Primary/High School Education & 77 & 74.0 & 120 & 70.6 & 197 & 71.9 & \\
\hline University Education & 2 & 1.9 & 5 & 2.9 & 7 & 2.6 & \\
\hline Income (minimum salaries) & & & & & & & 0.004 \\
\hline$\leq 3$ & 57 & 55.3 & 114 & 72.6 & 171 & 65.8 & \\
\hline$>3$ & 46 & 44.7 & 43 & 27.4 & 89 & 34.2 & \\
\hline Diabetes & 40 & 36.7 & 42 & 23.5 & 82 & 28.5 & 0.016 \\
\hline Heart Attack & 13 & 12.5 & 10 & 6.0 & 23 & 8.5 & 0.061 \\
\hline High Cholesterol & 34 & 32.7 & 80 & 47.3 & 114 & 41.8 & 0.017 \\
\hline Encephalic vascular accident & 8 & 7.7 & 9 & 5.3 & 17 & 6.2 & 0.432 \\
\hline Controlled Pressure $(<140 / 90 \mathrm{mmHg})$ & 58 & 52.7 & 116 & 64.4 & 174 & 60.0 & 0.048 \\
\hline Alcohol Consumption & & & & & & & $<0.0001$ \\
\hline No & 38 & 39.6 & 128 & 79.0 & 166 & 64.3 & \\
\hline Yes & 36 & 37.5 & 23 & 14.2 & 59 & 22.9 & \\
\hline Stopped & 22 & 22.9 & 11 & 6.8 & 33 & 12.8 & \\
\hline Smoking & 16 & 14.8 & 15 & 8.5 & 31 & 10.9 & 0.099 \\
\hline Physical activity & 41 & 38.0 & 53 & 29.8 & 94 & 32.9 & 0.153 \\
\hline Age (years) Average (Deviation from Standard) & \multicolumn{2}{|c|}{$61.2(10.8)$} & \multicolumn{2}{|c|}{$59.5(12.4)$} & \multicolumn{2}{|c|}{$60.1(11.8)$} & 0.099 \\
\hline Body mass index $\left(\mathrm{Kg} / \mathrm{m}^{2}\right)$ Average (Deviation from Standard) & \multicolumn{2}{|c|}{$28.7(5.4)$} & \multicolumn{2}{|c|}{$29.9(5.4)$} & \multicolumn{2}{|c|}{$29.5(5) 3}$, & 0.036 \\
\hline Abdomen circumference $(\mathrm{cm})$ Average (Deviation from Standard) & \multicolumn{2}{|c|}{ 102.3(14.3) } & \multicolumn{2}{|c|}{$98.9(116.5)$} & \multicolumn{2}{|c|}{ 100.2(12.8) } & 0.040 \\
\hline Systolic Pressure Average (Deviation from Standard) & \multicolumn{2}{|c|}{$142.5(23.5)$} & \multicolumn{2}{|c|}{$136.6(21.5)$} & \multicolumn{2}{|c|}{$138.8(22.4)$} & 0.008 \\
\hline Diastolic Pressure Average (Deviation from Standard) & \multicolumn{2}{|c|}{$82.6(12.9)$} & \multicolumn{2}{|c|}{$80.22(1.4)$} & \multicolumn{2}{|c|}{ 81.1(12.0) } & 0.073 \\
\hline
\end{tabular}

Value for Minimum Salary $=415$ Brazilian Real

$p<0.05)$. The variables in which the women greatly $(p<0.05)$ defer from the men are the following: anxiety, tension (76.7\% vs 59.8\%), sadness (57.6\% vs 33.6\%), easily frightened (48.2\% vs $21.5 \%)$, frequent headaches $(42.4 \%$ vs $26.2 \%)$, difficulties in making decisions (38.4\% vs 23.4\%), bad digestion (35.7\% vs 11.2\%), an upset stomach (35.5\% vs $22.4 \%$ ), crying (32.6\% vs 9.3\%), loss of interest in general things (30.2\% vs $15.0 \%)$, an incapacity to act in a useful way ( $28.5 \%$ vs $15.1 \%)$, difficulties in the work place $(26.9 \%$ vs $14.0 \%$ ) and feeling useless (22.8\% vs $11.2 \%)$.

Table 2 - Percentage distribution of those with hypertension, based on gender, responses to the questions from the Self Report Questionnaire and the presence of common mental disorders. São Paulo, SP, Brazil, 2010.

\begin{tabular}{|c|c|c|c|c|c|}
\hline \multirow[t]{3}{*}{ Variables } & \multicolumn{5}{|c|}{ Reponses } \\
\hline & \multicolumn{2}{|c|}{ No } & \multicolumn{2}{|c|}{ Yes } & \multirow[t]{2}{*}{ Value $p$} \\
\hline & $\mathbf{M}$ & W & M & W & \\
\hline Presence of a disorder & 69.2 & 37.2 & 30.8 & 62.8 & 0.000 \\
\hline \multicolumn{6}{|l|}{ In the last thirty days $\mathrm{Mr} / \mathrm{Mrs} / \mathrm{Ms}$} \\
\hline 01 - Do you have frequent headaches? & 73.8 & 57.6 & 26.2 & 42.4 & 0.006 \\
\hline 02 - Do you have a lack of appetite? & 74.8 & 76.2 & 25.2 & 23.8 & 0.792 \\
\hline 03 - Are you a bad sleeper? & 60.7 & 51.7 & 39.3 & 48.3 & 0.141 \\
\hline 04 - Are you easily frightened? & 78.5 & 51.8 & 21.5 & 48.2 & $<0.0001$ \\
\hline 05 - Does your hand tremble? & 79.4 & 76.7 & 20.6 & 23.3 & 0.599 \\
\hline 06 - Do you feel anxious $(\mathrm{m} / \mathrm{f})$, tense $(\mathrm{m} / \mathrm{f})$, worried $(\mathrm{m} / \mathrm{f})$ ? & 40.2 & 23.3 & 59.8 & 76.7 & 0.003 \\
\hline 07 - Do you have indigestion? & 88.8 & 64.3 & 11.2 & 35.7 & $<0.0001$ \\
\hline
\end{tabular}


...continuation

\begin{tabular}{|c|c|c|c|c|c|}
\hline \multirow[t]{3}{*}{ Variables } & \multicolumn{5}{|c|}{ Reponses } \\
\hline & \multicolumn{2}{|c|}{ No } & \multicolumn{2}{|c|}{ Yes } & \multirow[t]{2}{*}{ Value $p$} \\
\hline & M & W & M & W & \\
\hline 08 - Do you have difficulty in thinking clearly? & 64.5 & 53.5 & 35.5 & 46.5 & 0.071 \\
\hline 09 - Have you been feeling sad lately? & 66.4 & 42.4 & 33.6 & 57.6 & $<0.0001$ \\
\hline 10 - Have you been crying more than normal? & 90.7 & 67.4 & 9.3 & 32.6 & $<0.0001$ \\
\hline 11 - Have you been finding it difficult to carry out your daily activities? & 68.2 & 62.2 & 31.8 & 37.8 & 0.307 \\
\hline 12 - Do you have difficulties in making decisions? & 76.6 & 61.6 & 23.4 & 38.4 & 0.009 \\
\hline 13 - Do you have problems at your place of work? & 86.0 & 73.1 & 14.0 & 26.9 & 0.012 \\
\hline 14 - Are you not able to act in a useful way in your life? & 84.9 & 71.5 & 15.1 & 28.5 & 0.010 \\
\hline 15 - Have you been losing interest in things in general? & 85.0 & 69.8 & 15.0 & 30.2 & 0.004 \\
\hline 16 - Do you feel like you are someone who is useless and has no value? & 88.8 & 77.2 & 11.2 & 22.8 & 0.015 \\
\hline 17 - Have you been thinking of taking your own life? & 96.3 & 93.6 & 3.7 & 6.4 & 0.339 \\
\hline 18 - Do you feel tired $(\mathrm{m} / \mathrm{f})$ all the time? & 67.0 & 57.6 & 33.0 & 42.4 & 0.117 \\
\hline 19 - Do you have an upset stomach? & 77.6 & 64.5 & 22.4 & 35.5 & 0.021 \\
\hline 20 - Do you get tired easily? & 62.6 & 51.2 & 37.4 & 48.8 & 0.061 \\
\hline
\end{tabular}

$\mathrm{W}=$ women $\quad \mathrm{M}=\mathrm{men}$

In relation to Social Support, an analysis of the average scores showed a significant difference $(p<0.05)$ between men and women in this area. There was more support in this area given to the men, which can be seen in the question "whether you always have someone to help you to prepare your meals, if you could not do it yourself?". Women had a lower score for this question (69.6\% vs 84.0\%). However in the area of positive social interactions, women presented a higher frequency $(p<0.05)$ : in always having someone with whom they could do fun things (68.8\% vs 63.5\%), someone that could take their minds off things (72.6\% vs $64.5 \%)$ and someone with whom they could relax (70.2\% vs 66.4\%) (Table 3).

Table 3 - Percentage distribution of those with hypertension, based on gender and Social Support. São Paulo, SP, Brazil, 2010.

\begin{tabular}{|c|c|c|c|c|c|c|c|c|c|c|c|}
\hline \multirow[t]{3}{*}{ Questions } & \multicolumn{11}{|c|}{ The Scores for the questions } \\
\hline & \multicolumn{2}{|c|}{ Never (1) } & \multicolumn{2}{|c|}{ Rarely (2) } & \multicolumn{2}{|c|}{ Sometimes (3) } & \multicolumn{2}{|c|}{ Almost always (4) } & \multicolumn{2}{|c|}{ Always (5) } & \multirow[t]{2}{*}{ Value $p$} \\
\hline & $\mathbf{M}$ & W & M & W & M & W & M & W & M & W & \\
\hline \multicolumn{12}{|l|}{ If needed, how often can you count on someone... (\%) } \\
\hline \multicolumn{12}{|c|}{ Material Acts (Acts done to satisfy a physical need) (DP=Percentage Distribution)* average (DP) M=17.4 (4.6) W=16.5(4.6) } \\
\hline 1. Someone to help, if you are stuck in bed? & 6.6 & 6.5 & 3.8 & 11.2 & 4.7 & 11.2 & 4.7 & 4.7 & 80.2 & 66.5 & 0.058 \\
\hline 2. Someone to take you to the doctor? & 6.6 & 6.0 & 4.7 & 5.4 & 10.4 & 10.8 & 4.7 & 5.4 & 73.6 & 72.5 & 0.996 \\
\hline 3. Someone to do your daily tasks if you are ill? & 8.8 & 8.9 & 3.9 & 7.1 & 7.8 & 16.7 & 2.0 & 1.8 & 77.5 & 65.5 & 0.190 \\
\hline 4. Someone to prepare your meals if you can't? & 6.6 & 6.4 & 2.8 & 9.9 & 4.7 & 11.1 & 1.9 & 2.9 & 84.0 & 69.6 & 0.045 \\
\hline \multicolumn{12}{|c|}{ Emotional Acts, acts done to satisfy an emotional need, average (DP) $M=13.5(2.5) \mathrm{W}=13.5(2.5)$} \\
\hline 5. Someone that shows love and affection towards you? & 0.0 & 1.2 & 7.5 & 4.2 & 6.5 & 4.8 & 5.6 & 7.8 & 80.4 & 82.0 & 0.493 \\
\hline 6. Someone that can give you a hug? & 1.9 & 1.8 & 6.6 & 2.9 & 9.4 & 6.5 & 5.7 & 8.8 & 76.4 & 80.0 & 0.443 \\
\hline 7. Someone that loves you and makes you feel loved? & 2.8 & 0.6 & 3.8 & 4.7 & 6.6 & 3.5 & 7.5 & 7.1 & 79.2 & 84.1 & 0.418 \\
\hline \multicolumn{12}{|c|}{ Other Emotional Needs average (DP) $M=16.9(4.4) W=16.9(4.3)$} \\
\hline $\begin{array}{l}\text { 8. Someone to listen to you when you need to speak to } \\
\text { someone? }\end{array}$ & 2.8 & 3.6 & 8.4 & 5.3 & 12.1 & 7.7 & 5.6 & 8.9 & 71.0 & 74.6 & 0.481 \\
\hline $\begin{array}{l}\text { 9. Someone who you can trust and tell your problems } \\
\text { to? }\end{array}$ & 4.8 & 5.4 & 10.5 & 4.8 & 12.4 & 7.2 & 3.8 & 6.6 & 68.6 & 76.0 & 0.176 \\
\hline 10. Someone to share your worries and fears? & 6.7 & 3.6 & 9.6 & 9.1 & 11.5 & 9.1 & 2.9 & 6.1 & 69.2 & 72.1 & 0.546 \\
\hline 11. Someone who can understand your problems? & 1.9 & 2.4 & 7.5 & 9.0 & 12.3 & 9.6 & 4.7 & 7.2 & 73.6 & 71.9 & 0.855 \\
\hline \multicolumn{12}{|c|}{ The Provision of Information, average (DP) (DP) $M=16.4(5.1) \mathrm{W}=16.6(4.5)$} \\
\hline 12. Someone that can give advice when in a crisis? & 2.9 & 5.5 & 4.9 & 2.4 & 13.7 & 10.9 & 4.9 & 6.1 & 73.5 & 75.2 & 0.623 \\
\hline $\begin{array}{l}\text { 13. Someone that gives information in order for you to } \\
\text { understand a situation? }\end{array}$ & 3.8 & 3.7 & 6.7 & 6.2 & 14.4 & 9.3 & 2.9 & 6.8 & 72.1 & 73.9 & 0.497 \\
\hline 14. Someone that real wants advice? & 9.9 & 5.5 & 9.9 & 10.3 & 6.9 & 12.7 & 5.0 & 4.2 & 68.3 & 67.3 & 0.430 \\
\hline
\end{tabular}




\begin{tabular}{|c|c|c|c|c|c|c|c|c|c|c|c|}
\hline \multirow[t]{3}{*}{ Questions } & \multicolumn{11}{|c|}{ The Scores for the questions } \\
\hline & \multicolumn{2}{|c|}{ Never (1) } & \multicolumn{2}{|c|}{ Rarely (2) } & \multicolumn{2}{|c|}{ Sometimes (3) } & \multicolumn{2}{|c|}{ Almost always (4) } & \multicolumn{2}{|c|}{ Always (5) } & \multirow[t]{2}{*}{ Value $p$} \\
\hline & M & W & $\mathbf{M}$ & W & M & W & $\mathbf{M}$ & W & $\mathbf{M}$ & W & \\
\hline $\begin{array}{l}15 . \text { Someone that gives suggestions for personal } \\
\text { problems? }\end{array}$ & 3.9 & 4.9 & 10.8 & 8.5 & 9.8 & 9.8 & 3.9 & 7.3 & 71.6 & 69.5 & 0.789 \\
\hline \multicolumn{12}{|c|}{ Positive Interactions, average (DP) $M=12.5(3.3) \mathrm{W}=12.8(3.3)$} \\
\hline 16. Someone to do fun things with? & 2.9 & 7.6 & 10.6 & 5.9 & 19.2 & 10.0 & 3.8 & 7.6 & 63.5 & 68.8 & 0.037 \\
\hline 17. Someone to take your mind off things? & 0.9 & 4.2 & 10.3 & 7.1 & 22.4 & 8.3 & 1.9 & 7.7 & 64.5 & 72.6 & 0.002 \\
\hline 18. Someone with whom you can relax? & 0.0 & 5.3 & 11.2 & 4.7 & 17.8 & 12.9 & 4.7 & 7.0 & 66.4 & 70.2 & 0.023 \\
\hline
\end{tabular}

* $p<0.05 \quad \mathrm{~W}=$ women $\quad \mathrm{M}=\mathrm{men}$

\section{DISCUSSION}

The main finding of the study, in spite of the presence of unfavorable factors, (such as: low income, high body mass index, less social support and a higher percentage of women with common mental disorders) was that women had better values for blood pressure control than men. Such a result may be due to women having a more accurate understanding of their health and well-being and thus take the time to seek out health care and will normally follow any treatment that is proposed. However gender differences deserve special attention in the context of hypertension. Studies have shown that women form the majority of the population with hypertension that use basic health care services ${ }^{(12-14)}$.

In relation to controlling arterial hypertension, in general, the data is very much mixed. Having conducted a detailed study ${ }^{(15)}$ of the medical journals which covered studies done in Brazil, it was found that São José do Rio Preto (in Sao Paulo state) had the highest number of those that controlled their condition. On the other hand Rio Grande do Sul and Santa Catarina had the lowest percentage which was about $10 \%$. A study ${ }^{(16)}$ that analyzed data from the HIPERDIA program in a city in the south of the country, showed that $37.6 \%$ of women had their blood pressure controlled in comparison with $25 \%$ of men. Similarly, in an investigation ${ }^{(6)}$ done on the Basic Health Centers in Sao Paulo, the control was higher for women (52.6\% vs 30.9\%). In the city of Nobres in the central-western region the numbers were $47.7 \%$ vs $30.3 \%$, respectively ${ }^{(14)}$. In reports of hypertension where there was self-referrals in 100 Brazilian municipalities, it was also shown that women had more control $(39,1 \% \text { vs } 50 \%)^{(17)}$.

In the analysis of the profiles of women with hypertension, what was noted was the presence of variables that hindered the process of sticking to treatment and consequently had a bearing on the control over blood pressure. One such variable was a low income. An investigation ${ }^{(18)}$ done in the hospital complex called the Clinical Hospitals in Sao Paulo, which involved evaluating the prevalence of arterial hypertension amongst their staff and biosocial aspects of their lives, it was found that those with high blood pressure earned up to five minimum salaries. It should also be noted that women's wages tend to be less when compared with their male counterparts exercising the same role ${ }^{(19)}$. The association between low spending power and arterial hyper- tension shows that inadequate life conditions predisposes someone or can be associated with a high prevalence of arterial hypertension. There is also a high prevalence of risk factors facilitating rises in blood pressure ${ }^{(12,20)}$. Therefore it can be said that socioeconomic differences play an important role in a person's state of health due to: the presence of poor eating habits, less access to health care and relevant information, not much understanding of the problem, sticking to (or not) any prescribed treatment and psychosocial stress.

The presence of comorbidities, which are also related to cardiovascular risk factors, were stark in women, when compared to men due to: the high presence of diabetes, high cholesterol levels, wide circumference abdomens and high body mass indexes. These conditions may be related to the age group that was predominant in the group that was studied which was those in their sixties. Upon analyzing arterial hypertension between men and women up to the menopause, women presented a lesser prevalence of hypertension and related illnesses. However, after the menopause, women tend to presence a prevalence of arterial hypertension similar to the men ${ }^{(4)}$. The following are the principal factors associated with a high prevalence of arterial hypertension in women in the menopause: a reduction in the production of estrogen, alterations in bodily fluids, weight gain and sedentary life style. This is the case when a comparison is made with those in the premenopausal phase of life.

The international study INTERHEART ${ }^{(21)}$, which involved a systematic study of the importance of risk factors for coronary diseases, showed that smoking and dyslipidemia made up for more than two thirds of these risks. Also the following factors played a significant role: pychosocial factors, obesity, diabetes mellitus and arterial hypertension. Similarly we noted close relations with these factors and cardiovascular problems ${ }^{(22-23)}$. However in relation to alcohol consumption, the women deferred from the men due to their lower levels of consumption. The relationship between arterial hypertension and alcohol consumption has been well documented and referred to in studies ${ }^{(24-25)}$. The VI Brazilian Guidelines on Hypertension ${ }^{(4)}$ has set the maximum tolerance of $30 \mathrm{~g}$ for ethanol per day, however this value drops to half for women.

In this study, those with hypertension were evaluated in relation to social support. The findings, which we considered interesting, was that women with hypertension had more support that men in the area of interaction. This may well 
be explained by women's roles in the family setting and their propensity to maintain and establish effective relationships. This support, although it is not just based around the family but also comes from friends and neighbors, it can benefit those with hypertension who are trying to handle their situation. We noted that social links had an influence on maintaining a person's health, and allowed for behaviors to be modified when in stressful situations. A social network was also seen as beneficial for health and well-being ${ }^{(26)}$. Continuing on the same vein, a qualitative study carried out on elderly people with hypertension showed that friendships are important sources of support which enables links to be stronger than blood ties ${ }^{(27)}$. This support network can have a fundamental role in the process of adhering to prescribed treatment for chronic diseases such as arterial hypertension. The anti-hypertensive treatment involves pharmacological medication and treatment without medication. In many cases it requires changes in habits and life styles. Complex therapeutic programs consisting of anti-hypertensive drugs which cover the most frequent comorbidities, require the adoption of strategies designed to avoid those forgetting that families can be extremely useful. Also relying on a network of friends, neighbors or communities are alternatives to practicing physical activity. They are also fundamental in controlling tension levels and a person's weight.

In the psycho-emotional context through an evaluation of common mental disorders, it was shown that women had more problems in this are than the men. This corroborated what has been written in medical journals ${ }^{(28-29)}$. This it can be stated that social determinants for this illness can explain the findings particularly when looking at the poor pyscho-emotional contexts that some women find themselves in. This is also connected to low salary incomes for women in the study with hypertension. The theory of life events state that stressful events cause changes in the endocrine system which increases the chances of the development of diseases and problems such as mental disorders ${ }^{(30)}$. Emotional stress palys a part in triggering and maintaining hypertension. It can also act to stop people from adhering to treatment. Another reason why mental disorders were more prevalent in women can be attributed to the gender dynamic where women are often in a position of being oppressed due to their gender. In an article on inequality and mental disorders in women, an author highlighted the following influential factors: low selfesteem, little control over their life context, and low value placed on women in business in societies. When women's health starts to fail due to the aforementioned, they seek help from health services more so than men. Another aspect worth highlighting in relation to women in the work place is that they bring their traditional attributes to any new work place role. The result of this is that they end up working longer hours, fatigue sets in, they succumb to stress and they develop psychiatric symptoms ${ }^{(31)}$.

\section{Limitations of The Study}

The main limitation of this study relates to the type of study that was carried out. Studies which are by their very nature observational, do not allow evaluations on relationships between cause and effect, in spite of the association between the studied variables and controlling arterial hypertension. Another limitation relates to the fact that the study was based on a specific sample of those with hypertension that received care at basic health centers in the western region of the city of Sao Paulo. Widening the study to other regions and cities would be useful because one could analyze whether the phenomenon repeated itself.

\section{CONCLUSION}

This studied showed that, in synthesis, women with hypertension present higher levels of control over their blood pressure than men in spite of there being unfavorable factors that hinder their control. It can be said that women's nature has a protective quality in relation to hypertension.

Noting that the main purpose of anti-hypertensive treatment is to reduce morbidity and mortality rates due to high blood pressure, it is incumbent upon nurses to take a more individualized approach when caring for suffers which prioritizes the real necessities of those with hypertension. Special attention should be placed on gender differences. When planning health care actions, emphasis should be placed on providing conditions to maximize the control over arterial hypertension. This is particularly relevant in the basic health care context where the majority of those with hypertension are treated. There should be monitoring of those with hypertension particularly for: those who have not managed to control the disease and those with comorbidities (such as diabetes, obesity, changes in bodily fluids) and those with negative psychosocial characteristics. These people require special attention which should include monthly visits done by community health care workers. Follow up calls should be made where appointments are missed and periodic checks should be done by nurses.

What should be noted is that controlling arterial hypertension in many cases, is related to the patients not adhering to the required treatment. The factors that cause this situation should be identified as soon as is possible. Also in relation to psycho-emotional aspects and social support networks, the use of evaluation tools can be extremely useful.

\section{RESUMO}

Objetivo: Comparar mulheres e homens hipertensos quanto ao controle da hipertensão arterial, variáveis biossociais, hábitos e estilos de vida, transtornos mentais comuns e apoio social. Método: Foram analisados 290 hipertensos (62,1\% mulheres). A pressão arterial foi medida com aparelho automático; avaliação social pela Escala de Apoio Social; e transtornos mentais comuns pelo Self Report Questionnaire, $\mathrm{p}<0,05$ foi considerado significante. Resultados: As mulheres foram diferentes dos homens $(\mathrm{p}<0,05)$ nos seguintes aspectos: pressão mais controlada (64,4\% vs 52,7\%); menor renda salarial; menos Diabetes; colesterol total mais elevado; maior índice de massa corporal e de circunferência abdominal; pressão sistólica menor; menor ingestão de bebidas alcoólicas; e mais presença de 
transtornos mentais comuns. A avaliação do apoio social revelou que as mulheres tinham menos ajuda no preparo de refeições, porém mais companhia para atividades agradáveis e diversão. Conclusão: Verificou-se que mulheres hipertensas estavam mais controladas que os homens, apesar da existência de variáveis biopsicossociais negativas que podem influenciar a adesão ao tratamento.

\section{DESCRITORES}

Pressão Arterial; Mulheres; Homens; Hipertensão.

\section{RESUMEN}

Objetivo: Comparar a mujeres y hombres hipertensos en cuanto al control de la hipertensión arterial, variables biosociales, hábitos y estilos de vida, desórdenes mentales comunes y apoyo social. Método: Fueron analizados 290 hipertensos (el 62,1\% de mujeres). La presión arterial fue medida con aparato automático; evaluación social por la Escala de Apoyo Social; y desórdenes mentales comunes por Self Report Questionnaire, $\mathrm{p}<0,05$ fue considerado significativo. Resultados: Las mujeres fueron distintas de los hombres ( $<<0,05)$ en los siguientes aspectos: presión más controlada (el 64,4\% vs el 52,7\%); menores ingresos; menos Diabetes; colesterol total más elevado; mayor índice de masa corpórea y de circunferencia abdominal; presión sistólica menor; menor ingesta de bebidas alcohólicas; y más presencia de desórdenes mentales comunes. La evaluación del apoyo social desveló que las mujeres tenían menos ayuda en la preparación de las comidas, pero más compañía para actividades agradables y de ocio. Conclusión: Se verificó que las mujeres hipertensas estaban más controladas que los hombres, pese a la existencia de variables biopsicosociales negativas que pueden influenciar la adhesión al tratamiento.

\section{DESCRIPTORES}

Presión Arterial; Mujeres; Hombres; Hipertensión.

\section{REFERENCES}

1. Goulart FAA. Doenças crônicas não transmissíveis: estratégias de controle e desafios para os sistemas de saúde. Brasília: Organização Pan-Americana de Saúde; 2011.

2. Pereira M, Lunet N, Azevedo A, Barros H. Differences in prevalence, awareness, treatment and control of hypertension between developing and developed countries. J Hypertens. 2009;27(5):963-75.

3. Brasil. Ministério da Saúde; Secretaria de Vigilância em Saúde. Vigitel Brasil 2014: vigilância de fatores de risco e proteção para doenças crônicas por inquérito telefônico [Internet]. Disponível em: http://portalsaude.saude.gov.br/images/pdf/2014/abril/30/Lancamento-Vigitel28-04-ok.pdf

4. Sociedade Brasileira de Cardiologia; Sociedade Brasileira de Hipertensão; Sociedade Brasileira de Nefrologia. VI Diretrizes Brasileiras de Hipertensão Arterial [Internet]. São Paulo; 2010 [citado 2014 nov. 16]. Disponível em: http://www.sbh.org.br/medica/diretrizes.asp

5. Gorgui J, Gorshkov M, Khan N, Daskalopoulou SS. Hypertension as a risk factor for ischemic stroke in women. Can J Cardiol. 2014;30(7):774-82.

6. Pierin AMG, Marroni SN, Taveira LAF, Benseñor IJM. Controle da hipertensão arterial e fatores associados na atenção primária em Unidades Básicas de Saúde localizadas na Região Oeste da cidade de São Paulo. Ciênc Saúde Coletiva. 2009;16(1):1389-400.

7. Goldberg D, Huxley P. Common mental disorders: a bio-social model. London: Tavistock; 1992.

8. O'Brien E, Mee F, Atkins N, Thomas M. Evaluation of three devices for selfmeasurement of blood pressure according to the revised British Hypertension Society protocol: the Omron HEM-705CP, Philips HP5332, and Nissel DS-175. Blood Press Monit. 1996;1(1):55-61.

9. Meneses-Gaya C, Zuardi AW, Loureiro SR, Crippa JAS. Alcohol Use Disorders Identification Test (AUDIT): an updated systematic review of psychometric properties. Psychol Neurosci. 2009;2(1):83-97.

10. Mari JJ, Willians P. A validity study of a psychiatric screening questionnaire (SRQ-20) in primary care in city of São Paulo. Br J Psychiatry. $1986 ; 148: 23-6$

11. Lopez C, Faerstein E, Chor D. Apoio social: confiabilidade teste-reteste de escala no Estudo Pró-Saúde. Cad Saúde Pública. 2003;19(2):625-34.

12. Noblat ACB, Lopes MB, Lopes AA. Complicações da hipertensão arterial em homens e mulheres atendidos em um ambulatório de referência. Arq Bras Cardiol. 2004;83(4):308-13.

13. Araújo JC, Guimarães AC. Controle da hipertensão arterial em uma unidade de saúde da família. Rev Saúde Pública. 2007;41(3):368-74.

14. Rosário TM, Scala LC, França GV, Gomes MR, Jardim PCBV. Prevalência, controle e tratamento da hipertensão arterial sistêmica em Nobres - MT. Arq Bras Cardiol. 2009;93(6):672-8.

15. Pinho NA, Pierin AMG. O controle da hipertensão arterial em publicações brasileiras. Arq Bras Cardiol. 2013;101(3):65-73.

16. Souza CS, Stein AT, Bastos GAN. Blood pressure control in hypertensive patients in the "Hiperdia Program": a territory-based study. Arq Bras Cardiol. 2014; 102(6):571-578.

17. Piccini RX, Facchini LA, Tomasi E, Siqueira FV, Silveira DS, Thumé E, et al. Promotion, prevention and arterial hypertension care in Brazil. Rev Saúde Pública 2012;46(3):543-50.

18. Mion Júnior D, Pierin AMG, Bambirra AP, Assunção JA, Monteiro JM, Chinen RY et al. Hypertension in employees of a University General Hospital. Rev Hosp Clin Fac Med S Paulo. 2004;59(6):329-36.

19. Machado LZ. Gênero e direitos humanos: revolução de idéias e políticas públicas. In Beltrão JF, Brito Filho JCM, Gómez I, Pajares E, Paredes F, Zúñiga Y. Direitos humanos dos grupos vulneráveis: manual. Barcelona: Rede Direitos Humanos e Educação Superior; 2014. p.131-44.

20. Hartmann M Dias-da-Costa JS, Olinto MTA, Pattussi MP, Tramontini A. Prevalência de hipertensão arterial sistêmica e fatores associados: um estudo de base populacional em mulheres no Sul do Brasil. Cad Saúde Pública. 2007;23(8):1857-866. 
21. Yusuf S, Hawken S, Ounpuu S, Dans T, Avezum A, Lanas F, et al.; INTERHEART Study Investigators. Effect of potentially modifiable risk factors associated with myocardial infarction in 52 countries (The INTERHEART study): case-control study. Lancet. 2004;364(9438):937-52.

22. Moraes SA, Checchio MV, Freitas ICM. O efeito independente da obesidade central sobre a hipertensão arterial em adultos residentes em Ribeirão Preto, SP, 2007. Projeto EPIDCV. Rev Bras Epidemiol. 2015;18(1):157-73.

23. Cunha e Silva DC, Lourenco RW, Cordeiro RC, Rica MRD. Análise da relação entre a distribuição espacial das morbidades por obesidade e hipertensão arterial para o estado de São Paulo, Brasil, de 2000 a 2010. Ciênc Saúde Coletiva. 2014; 9(6):1709-19.

24. Husain K, Ansari RA, Ferder L. Alcohol-induced hypertension: mechanism and prevention. World J Cardiol. 2014;6(5):245-52.

25. Mendes TA Goldbaum M, Segri NJ, Barros MB, César CL, Carandina L. Factors associated with the prevalence of hypertension and control practices among elderly residents of São Paulo city, Brazil. Cad Saúde Pública. 2013;29(11):2275-86.

26. Griep RH, Chor D, Faerstein E, Werneck GL, Lopes CS. Validade de constructo de escala de apoio social do Medical Outcomes Study adaptada para o português no Estudo Pró-Saúde. Cad Saúde Pública. 2005;21(3):703-14.

27. Faquinello P, Marcon SS. Friends and neighbors: an active social network for adult and elderly hypertensive individuals. Rev Esc Enferm USP [Internet]. 2011 [cited 2014 Nov 16] ;45(6):1345-52. Available from: http://www.scielo.br/pdf/reeusp/v45n6/en_v45n6a10.pdf

28. Moreira JKP, Bandeira MC, Scalon JD. Prevalência de transtornos mentais comuns e fatores associados em uma população assistida por equipes do Programa Saúde da Família. J Bras Psiquiatr. 2011;60(3):221-6.

29. Costa MGS, Dimenstein MDB, Leite JF. Condições de vida, gênero e saúde mental entre trabalhadoras rurais assentadas. Estud Psicol (Natal). 2014;19(2):145-54.

30. Lopes SC, Faerstein E, Chor D. Eventos de vida produtores de estresse e transtornos mentais comuns: resultados do Estudo Pró-Saúde. Cad Saúde Pública. 2003; 19(6):1713-20.

31. Ludermir AB. Desigualdades de classe e gênero e saúde mental nas cidades. Physis Rev Saúde Coletiva. 2008;18(3):451-67. 